\title{
The Effect of Written Corrective Feedback on Omani Students' Accuracy in the Use of English Prepositions
}

\author{
Ahmed Ali Saleh Al Ajmi \\ Department of English Language \& Literature (DELL), Rustaq College of Applied Sciences, Oman \\ E-mail: ahmed.ali.alajmi@gmail.com
}

\author{
Doi:10.7575/aiac.alls.v.6n.1p.61 \\ URL: http://dx.doi.org/10.7575/aiac.alls.v.6n.1p.61
}

Received: $14 / 09 / 2014$

Accepted: 19/11/2014

\begin{abstract}
A quasi-experimental study was conducted to examin the effectiveness of providing written corrective feedback (WCF) to Arab speakers of English on ten uses of English prepositions. Arab speakers commonly find it difficult to correctly use English propositions, mainly due to the differences between the two languages (e.g. Ortega, 2009). Examples of prepositions misuse are "married from," "die from," and "kind with." The WCF implementation lasted for seven weeks. The students' being in intact classes made random assignments to different groups difficult. The data were derived from three tests: pre-test, immediate post-test and delayed post-test as well as an open-ended questionnaire. The experimental group $(n=25)$ received WCF on their writing, oral meta-linguistic tutorials, and a treatment task for their pre-test. For both the immediate post-test and the delayed post-test, they only received WCF on their writings. The control group ( $\mathrm{n}=$ 25) only received general comments, like "good organization of the story events." The statistical results of the independent samples t-test show the experimental group outperforming the control group on the target features. The analysis of the questionnaire data also shows the benefits of WCF for improving preposition use. The results also have pedagogical implications with regard to WCF.
\end{abstract}

Keywords: WCF, writing, prepositions, students'views, Arabic, EFL

\section{Introduction}

According to Nicol and Macfarlane-Dick (2006), feedback is information about students' progress and performance. Feedback on ESL (English as a Second Language)/ EFL (English as a Foreign Language) writing is still debatable (Bitchener \& Knoch, 2009a). For instance, the debate includes such questions as how students respond to feedback on their writing, what teachers think about feedback, and what the best type of feedback is. In regard to the significance of feedback, Brick (2004) and Ferris (1999) underline the fact that feedback is not only valued by students, but also teachers find it of paramount importance. Furthermore, research on students' attitudes towards teacher feedback shows that ESL/EFL writing students appreciate the importance of feedback and that they consider it essential (Ferris \& Roberts, 2001; Hyland, 1998; Lee, 2004). They, according to Qi and Lapkin (2001), want their errors to be corrected.

Given the situation, more research is needed to explore the effectiveness of written corrective feedback (WCF). Bitchener and Knoch (2009a), for example, pointed out that further research is required in order to "investigate its effect on other linguistic error categories" (p. 208). Accordingly, the current study is contributing to the research on WCF through this paper by specifically examining a new "linguistic error category": Arab speakers' use of prepositions in English. The target language features, which will be looked at in detail in the methodology section, are commonly confused by Arab speakers due to L1 interference and literal translation (Kharma \& Hajaj, 1997; Ortega, 2009). This study is expected to bridge the gap in the literature and to provide more evidence of WCF's effectiveness.

\section{Literature Review}

\subsection{Language Acquisition and Corrective Feedback}

Proponents of the innatist model of language learning have pointed out that language is not easily learned by normal input (Wexler \& Culicover, 1980; Pinker, 1989). Furthermore, Mitchell and Myles (2004) posed the question: "[H]ow are learners to discover the limits and boundaries of the language system they are learning?" (p. 177). In the light of this question, negative feedback, which is another form of corrective input (Saxon, 2010, p. 101), seems to be very important in assisting language learners to establish good language knowledge and usage. This kind of corrective input is not only used for second language learners but also in the case of first language acquisition.

In L1 acquisition, for example, Bohannon and Bonvillian (2009) noted that parents provide their children with some feedback and correction to their language use (p. 245). Fromkin, Rodman and Hyams $(2003 ; 2011)$ argued that children learn to produce good language if they are given feedback on their language production. They show a good example of how children learn through correction and reinforcement: 
CHILD: Nobody don't like me.

MOTHER: No, say "Nobody likes me."

CHILD: Nobody don't like me.

(dialogue repeated eight times)

MOTHER: Now listen carefully, say "Nobody likes me."

CHILD: Oh, nobody don't likes me.

(2003, p. 344; 2011, p. 326)

Based on this example, one could assume that White's (1989) argument on children's tendency to ignore corrective input is, to some extent, valid. However, in that example, learning was salient because, although it took time, the child did start using the third person singular "s" by the end of the dialogue. Accordingly, one might say that because people perfectly acquire their first languages, this kind of feedback rarely exists (Krashen, 1982, p. 11). In L2 learning, feedback is a valuable source of knowledge as it provides assistance to discovering the gaps and how one can avoid them (Gass \& Selinker, 2008). Some language teachers do not leave their L2 students' mistakes without correction (Hyland \& Ann, 2006; Roberts \& Cimasko, 2008). Along these lines, Chandler (2003) found out that students do not like being deprived of feedback on their errors. At the beginning of Chandler's study, the participants asked if they were going to receive WCF on their work. Students' desire for WCF could be attributed to their cultural beliefs. That is, according to Hyland and Anan (2006), in some cultures, students want to see their writing as error free because this is seen as a good command of language (p. 515).

\section{2. Written Corrective Feedback}

Scholars have conducted research on the types of feedback students receive on their writing and their long-term effects. Bitchener, Young, and Cameron (2005), for example, distinguished direct from indirect feedback. When using direct feedback, teachers point out the errors and provide the corrections (Bitchener et al., 2005; Ferris, 2003; Lightbown \& Spada, 2006; Paltridge, Harbon, Hirsch, Shen, Stevenson, Phakiti, \& Woodrow, 2009). Doing this, according to Bitchener (2008) and Bitchener and Knoch (2008, 2009a, 2009b), could involve (1) the teacher's crossing out the wrong or unnecessary linguistic errors and providing corrections, (2) written meta-linguistic explanations in which teachers provide students with rule explanations supported by examples, and/or (3) oral meta-linguistic explanation where the teacher explains rules, provides examples, and carries out discussion. When they use indirect feedback, teachers indicate the errors without providing corrections, leaving the students to discover the errors for themselves (Bitchener et al., 2005; Ferris, 2003; Ferris \& Roberts, 2001; Paltridge et al., 2009; Robb, Ross, \& Shortreed, 1986). (For examples on correction codes used for indirect feedback, see Paltridge et al., 2009, p. 123 and Storch and Wigglesworth, 2010, p. 332.) Some studies have focused on the effectiveness of the different types of feedback, direct and indirect, by making comparisons between them. (See Lalande, 1982; Robb, Ross \& Shortreed, 1986; Ferris, 1997.) Chandler's (2003) study showed that direct feedback is more effective, while Lalande's (1982) research indicated that indirect feedback is more effective. Other studies have shown no difference in the effectiveness of the two types of feedback (Robb, Ross, \& Shortreed, 1986; Ferris \& Roberts, 2001). Additionally, some researchers have looked at students' feedback preferences and found indirect feedback to be the most preferred (Brandl, 1995; Ferris \& Roberts, 2001).

Some studies have emphasized the role of feedback on student writing (Ashwell, 2000; Bitchener, Young, \& Cameron, 2005; Bitchener, 2008; Bitchener \& Knoch, 2008, 2009a, 2009b; Chandler, 2003; Ellis, Sheen, Murakami, \& Takashima, 2008; Ferris, 1995, 1999, 2002; Ferris \& Roberts, 2001; Hyland, 1998; Sachs \& Polio, 2007; Sheen, 2007; Sheen, Wright, \& Moldawa, 2009). Most of these studies have two comparison groups while some do not, such as Chandler's (2003) study in Hong Kong. Some researchers pointed out that WCF is effective when it is attributed to certain characteristics. That is, for example, studies found that WCF is effective over time for specific language forms and structures (Ashwell, 2000; Bitchener, 2008; Bitchener \& Knoch, 2008; Bitchener, Young, \& Cameron, 2005; Chandler, 2003; Ellis, Sheen, Murakami, \& Takashima, 2008; Ferris, 1997; Ferris \& Roberts, 2001). Some have also highlighted that clarity and consistency of error correction are of paramount importance in assisting students to accurately use the linguistic forms (Ferris, 1999). Some researchers have claimed that ignoring error correction might lead to fossilization (Ferris, 2004; Han, 2004; Kepner, 1991). However, some studies have shown that teacher feedback on student writing is ineffective and, to some extent, might negatively affect students' attitudes towards writing (Fazio, 2001; Kepner, 1991; Polio, Fleck, \& Leader, 1998; Sheppard, 1992; Truscott, 1996; 2004; 2007). Truscott (2004) argued that correcting students' errors, especially grammar, might negatively affect their fluency (p. 342). He also argued that no evidence based on research supports feedback and that feedback does not take into account second language acquisition theories in terms of how different aspects of language are acquired (Truscott, 2004; 2007). Some have also claimed that no concrete evidence supports WCF (Kepner, 1991; Polio, Fleck \& Leder, 1998; Truscott \& Hsu, 2008). Truscott $(1996 ; 1999 ; 2007 ; 2009)$ called for further research on the effectiveness of error correction on grammar mistakes.

A number of researchers have conducted studies in the area of WCF (Ashwell, 2000; Bitchener, 2008; Bitchener \& Knoch, 2008; 2009a; 2009b; Ferris \& Roberts, 2001; Polio et al., 1998). Most of these studies were quantitative research following experimental research design. For example, Ashwell (2000) studied 50 Japanese university students 
throughout one semester and found these students' accuracy improved when teachers provided the corrective feedback. Bitchener (2008) conducted a two-month study of 75 international ESL students in two schools in Auckland and found that WCF is effective. His published article "Evidence in Support for Written Corrective Feedback" reflects his findings. Kassim and $\mathrm{Ng}$ (2014) conducted a recent study that explored the effect of corrective feedback on students' accuracy in using prepositions in their written work. The 90 ESL students who took part in this 12 -week study were assigned to two treatment groups (focused indirect and unfocused indirect corrective feedback groups) and one control group. The researchers found that both treatment groups outperformed the control group and that no significant difference existed between the performances of the two treatment groups. (For a summary detailing some studies on WCF in terms of participants, type of WCF used, duration of the study, effectiveness of WCF, and the limitations of the study, see Bitchener, 2008.) Ferris (2010) summarized eight studies in terms of primary focus, design, existence of control group in the study, types of errors treated, and type of WCF provided (p. 187). Similarly, in a recent study, Bitchener (2012) summarized nine studies in terms of sample, students' proficiency level, treatment provided and the findings of each study (p. 354).

\section{Statement of the Problem}

Arab speakers find English prepositions difficult to use due to the differences between the two languages (see Khotaba, 2013). Very few studies have examined the effect of WCF on the use of prepositions and, as far as the researcher have been able to find in the reviewed literature, no such study has been conducted in the Omani context. Bitchener et al.'s (2005) study focused on the effect of both oral and written corrective feedback by means of pre-test, post-test and delayed post-test. The error types focused on were prepositions, articles, and simple past tense. For the present study, the researcher looked at the effect of WCF on ten commonly confused uses of prepositions by Arabic speakers of English. The effectiveness of WCF on the targeted features was measured at three times: before, immediately after, and two weeks after the treatment. I also explored students' perceptions of the type and of the effectiveness of WCF on their misuse of English prepositions in their writing.

\section{Objectives of the Study}

This study is an attempt to investigate the effects of WCF on Omani students' accuracy in the use of English prepositions. It also aims to explore the students' perceptions about the types and of the effectiveness of WCF on their misuse of English prepositions in their written work.

\section{Research Questions}

Based on the above mentioned problem, the study attempts to answer the following questions:

1) Does written corrective feedback (WCF) help Arabic learners of English improve their accuracy in the use of English prepositions over time?

2) What are these students' views about the type and effectiveness of WCF on their misuse of English prepositions in their writings?

\section{Methodology}

\subsection{Context of the Study}

This study was conducted in the Department of English Language and Literature in an Omani college. Students who join this college are streamed into four levels (A, B, C, and D) based on their performance on a placement test at the very beginning of their first academic year. This placement test mainly focuses on reading, writing, and grammar, and it lasts for two hours. This programme is called the National Foundation Programme (NFP) where students are academically prepared before they join their main majors, which are Bachelor of Education in English, International Business Administration, or Information Technology.

\subsection{Participants}

The students who participated in this study were foundation year students studying English Level B in the NFP. Level B students are pre-intermediate in English, with Arabic as their mother tongue. All of the participants have spent almost 12 years studying English as one of the main subjects in school. Students at foundation Level B study the four skills (reading, writing, listening \& speaking) with different teachers. However, the four skills are not always treated equally as the focus is sometimes tilted to their weaknesses, such as in writing. The teaching approach could be classified as communicative. The participants were divided in two groups of 25: the experimental group $(\mathrm{n}=25)$ and the control group $(\mathrm{n}=25)$.

\subsection{Research Design}

To answer the first research question, a quasi-experimental design was used due to the difficulty of randomly assigning the 50 participants into control and treatment groups. In fact, random assignment of students is commonly impossible in educational institutions (Gass, 2010, p. 11; Dörnyei, 2007, p. 117). The number of students in each group was equal, 25 students each. These Arabic speakers' accuracy in using ten commonly confused English preposition usages (see Appendix 1) was measured over seven weeks by means of pre-test, immediate post-test, and delayed post-test, following the design of Bitchener and Knoch (2008), but with only two groups of participants. Accuracy needs to be tested in the form of pre-test and post-test, and all of the writing is new, not rewrites (Bitchener, 2008; Bruton, 2009; Sheen, 2007; Truscott, 1999, 2007). Furthermore, researchers have highlighted the value of assessing students' subsequent writings in order to find the effectiveness of WCF on, for example, linguistic features (Bitchener, 2008; 
Bitchener \& Knoch, 2008, 2009; Ellis et al., 2008; Bruton, 2009; Guénette, 2007; Truscott, 2007). The current study follows these studies in terms of looking at new pieces of writing with the focus on the same language features throughout all three tests.

To answer the second research question, an open-ended questionnaire was administered to the experimental group. According to Wagner (2010), "Questionnaires can be either closed or open-ended" (p. 27). The rationale behind choosing an open-ended questionnaire for this study was to explore students' views about the type and effectiveness of WCF on their misuses of English prepositions, and this type of questionnaire can provide rich data and help identify issues that had not previously anticipated (Dörnyei, 2007; Dörnyei \& Taguchi, 2010).

\section{Research Procedure}

\subsection{Quasi-experimental Design}

Before conducting the study, a letter was written both to the dean of the college and to the head of the English department, asking for permission to conduct the study in the college. After receiving their approvals, a letter was written to the Level B teachers asking permission to use their students for the study. Having the green light from the teachers, the researcher asked the students to fill in a consent form and to sign it. However, before they completed their consent forms, they were briefed about the study, explaining that it would not affect their marks and that their writings would be anonymous. Then, the researcher followed this outlined procedure:

\begin{tabular}{|c|c|c|}
\hline \multirow[b]{2}{*}{ Week } & \multicolumn{2}{|c|}{ Procedure } \\
\hline & Experimental Group & Control Group \\
\hline 1 & $\begin{array}{l}\text { The researcher briefed about the study and gave } \\
\text { them a consent form to sign. }\end{array}$ & $\begin{array}{l}\text { The researcher briefed the students about } \\
\text { the study and gave them a consent form to } \\
\text { sign. }\end{array}$ \\
\hline 2 & Students sat for a pre-test (see Appendix 2) & Students sat for a pre-test (see Appendix 2) \\
\hline 3 & $\begin{array}{l}\text { The students had } 10 \text { minutes to look at the } \\
\text { WCF on their pre-test essays, } 15 \text { minutes for an } \\
\text { oral meta-linguistic tutorial, and then a } \\
\text { treatment task (see Appendix } 3 \text { ). Then they } \\
\text { received the immediate post-test. }\end{array}$ & $\begin{array}{l}\text { No WCF was provided on the target } \\
\text { features. The students had } 10 \text { minutes to } \\
\text { look at the general comments on their } \\
\text { writing. Then they received the immediate } \\
\text { post-test. }\end{array}$ \\
\hline 4 & $\begin{array}{l}\text { The students only received WCF on their } \\
\text { immediate post-test. }\end{array}$ & $\begin{array}{l}\text { They received general comments on their } \\
\text { immediate post-test. }\end{array}$ \\
\hline 5 & No activity this week & No activity this week \\
\hline 6 & $\begin{array}{l}\text { They received the delayed post-test without } \\
\text { being informed about it. }\end{array}$ & $\begin{array}{l}\text { They received the delayed post-test without } \\
\text { being informed about it. }\end{array}$ \\
\hline 7 & $\begin{array}{l}\text { They received their essays back with WCF on } \\
\text { the target features. }\end{array}$ & $\begin{array}{l}\text { They received their essays back with } \\
\text { general comments about their writing. }\end{array}$ \\
\hline
\end{tabular}

\subsection{Open-ended Questionnaire}

The questionnaire items were prepared and piloted for better quality. For ethical considerations, the researcher communicated the purpose of the questionnaire to the respondents, emphasized the confidentiality of the data the students would provide, informed them that this was not a test so there was no right or wrong answer, and informed them that the results of this survey would be communicated to them, if they wished, at the end of the study (see Dörnyei \& Taguchi, 2010). In order to make sure the respondents understood the questionnaire items, the researcher explained each item before the students started answering. All of the experimental group students $(n=25)$ responded to the four questions on the questionnaire (see Appendix 4) after the delayed post-test.

\section{Data Analysis}

\subsection{Quasi-experimental Design}

The researcher identified the use of the target prepositions for every single piece of writing in the two groups for the three tests, following Li's (2012) procedure. In regard to the control group, these features were identified on photocopies in order not to provide them with feedback on the target features (see Bitchener, 2008; Bitchener \& Knoch, 2009a). The error identification and correction were carried out by the researcher in order to maintain consistency in the feedback. One point was counted for each correct use of the targeted prepositions (1 point per correct use x 10 uses). To ensure inter-rater reliability, a second rater who is experienced in the field was asked to identify the target features of the study in the students' writings. The percentage of agreement between the two raters for the three tests was $92 \%$, $96 \%$, and $94 \%$, respectively. These percentages are quite acceptable, according to Salkind (2012), who explained: "[Y] ou should really expect nothing less than 90\%" (p. 112). In order to analyse the data obtained from the three tests, an independent samples t-test was used (Pallant, 2011; Yockey, 2011). 


\subsection{Open-ended Questionnaire}

The students' perceptions about the type and effectiveness of WCF on their misuse of English prepositions in their writing were examined in the open-ended questionnaire. The qualitative data were elicited through thematic analysis (Dörnyei \& Taguchi, 2010) which reflects students' viewpoints about WCF. The use of qualitative data enriches and supports the quantitative data (Dörnyei, 2007; Creswell, 2009; Creswell, 2014); therefore, the researcher used qualitative data alongside the quantitative data obtained by the three tests.

\section{Results}

\subsection{Quantitative Data}

To answer the first research question, an independent samples t-test was conducted to compare the scores for the experimental group and for the control group, between group comparisons, for the three tests (Pallant, 2011; Yockey, 2011). In the pre-test, no significant difference in scores surfaced between the experimental group $(M=1.68, S D=$ $1.07)$ and the control group $(M=1.44, S D=1.08),(t(48)=.788, p=.434$, two-tailed $)$, and the effect size was small $(d=0.23)$. For the immediate post-test, however, a significant difference arose as the experimental group's scores increased from the pre-test scores $(M=7.40, S D=2.22)$, while the control group's scores showed no significant increase $(M=1.08, S D=1.12),(t(35.41)=12.73, p=.00, t w o$-tailed $)$, and the effect size was large $(d=4.28)$. The scores for the delayed post-test also showed a significant difference in the experimental group scores as they remained higher, with a slight increase, than the immediate post-test scores $(M=8.08, S D=1.75)$ while the control group's scores showed no noticeable increase $(M=1.48, S D=1.08), t(48)=16.001, p=.000$, two-tailed $)$, and the effect size was large $(d=4.62)$.

Table 1 shows the descriptive statistics for the two groups over the three different testing periods. The mean scores refer to the mean percentage of accuracy in the use of the targeted prepositions.

Table 1. Descriptive statistics for mean test scores by group and testing period.

\begin{tabular}{lccccc}
\hline \multicolumn{1}{c}{ Group } & $\mathrm{N}$ & $\begin{array}{c}\text { Pre-test } \\
\text { Mean (SD) }\end{array}$ & $\begin{array}{c}\text { Immediate Post-test } \\
\text { Mean (SD) }\end{array}$ & \multicolumn{2}{c}{$\begin{array}{c}\text { Delayed Post-test } \\
\text { Mean (SD) }\end{array}$} \\
\hline Experimental group & 25 & $1.680(1.069)$ & 7.400 & $(2.217)$ & $8.080 \quad(1.754)$ \\
Control group & 25 & $1.440(1.083)$ & $1.080 \quad(1.115)$ & $1.480 \quad(1.085)$ \\
\hline
\end{tabular}

Note. The score range is $0-10$

Figure 1 provides a visual representation of the mean percentages for the three testing periods for each group. While the two groups were very similar before the treatment time (pre-test), the experimental group's accuracy in the use of the targeted prepositions significantly increased after the treatment time (immediate post-test), but no significant change took place in the control group. The mean scores for the delayed post-test, two weeks after the treatment, show that the experimental group was able to retain improvement in the use of the targeted features while the control group almost remained the same.
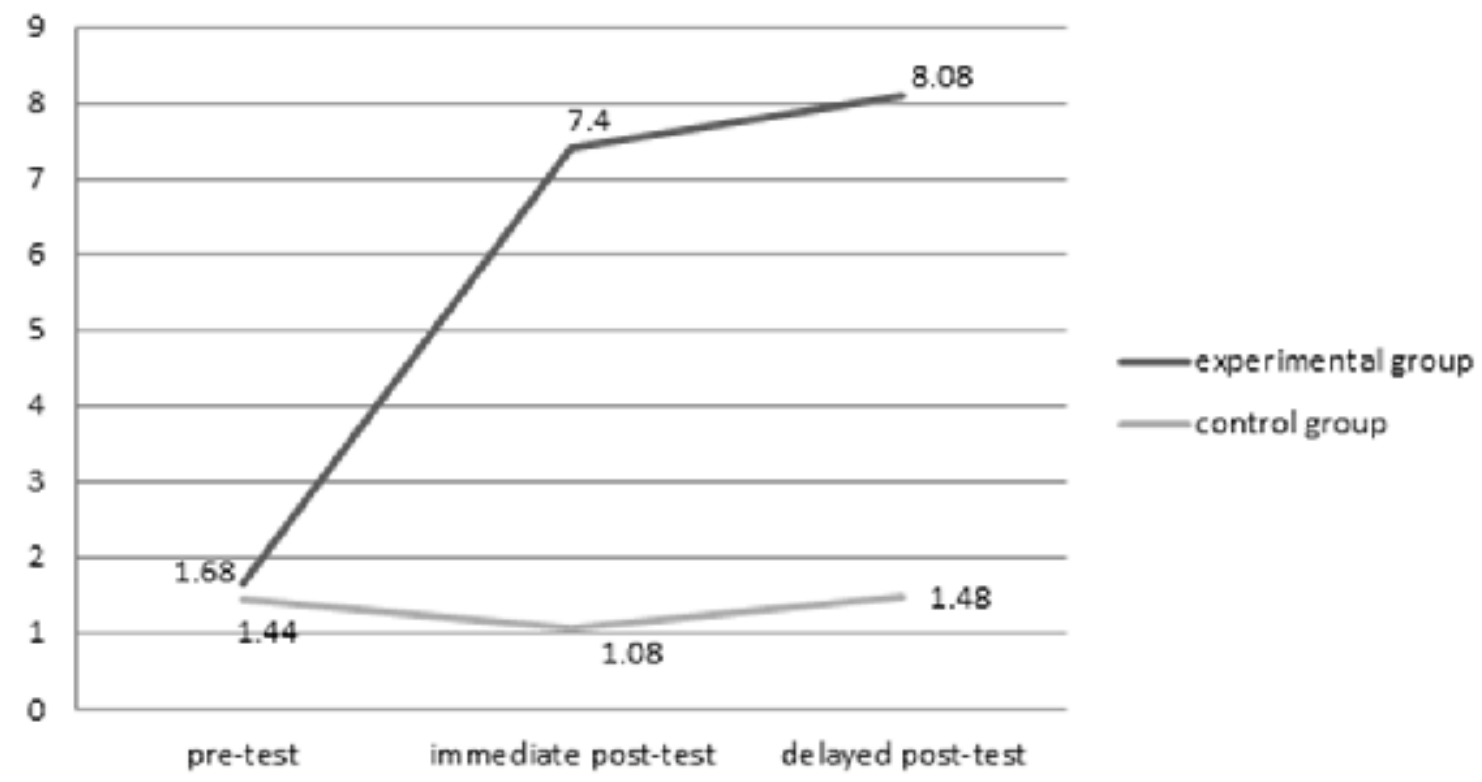

Figure 1. Mean percentage for the two groups over time 
The second research question was answered by the qualitative data generated through the open-ended questionnaire. The students' responses to the four open-ended questions were organized into themes, as follows:

\section{Type of feedback students usually receive on their misuse of English prepositions in their writing}

Almost half of the students, $48 \%$, indicated that they usually receive direct WCF on their misuse of English prepositions. One of these twelve students explained how the teachers responded to his mistakes by providing direct WCF, saying, "They deleted the wrong thing or the wrong words and write on it what kind of mistakes did we made then try to give as some example about how we using that in correct form." Another student said that the teachers "Underline the mistake and correct it and sometime circle the mistake and correct it." A third student wrote, "They notice us that there are preposition mistakes by making line under the mistake in the paper. They explain why it is wrong." Having the majority of teachers using direct WCF could be attributed to its effectiveness over the other types of WCF (Chandler, 2003).

Twenty-eight percent of the students indicated that they received both types of written corrective feedback, direct and indirect. For example, one student wrote, "Teachers indicate the wrong use of preposition by underlining it or crossing it. Some teachers cross it and write the correct one above it." Another student reported how his teacher gave direct WCF by crossing the wrong use and rewriting it, and sometimes providing correction codes: "The teacher dropped it and write again and some of them were only dropped and wrote 'Gr' and it meaned grammar mistakes." One of the respondents attributed the provision of direct or indirect WCF to the teacher: "It depend on the teachers. Some of them used the direct method in correction and the others used indirect." Some teachers' tendency to use both direct and indirect WCF could be explained by the fact that, as some researchers have pointed out, no significant difference exists in the effect on students' accuracy (Robb, Ross, \& Shortreed, 1986; Ferris \& Roberts, 2001).

Although some studies highlighted the effectiveness of indirect WCF (i.e. Lalande, 1982), only $24 \%$ of the students reported that they only receive indirect WCF. One of them reported, "Teachers tries to underline the place where prepositions aren't correct their and write up of it (pp)." Another student explained how the indirect WCF was provided to him at school, writing, "Actually in school years the teachers to put cycle or line under the word or prepositions wrong the then students to correct the wrong answer and at the end to check the answer."

\section{The type of feedback the students find effective for them}

Regarding the students' views about which type of WCF is effective for them, $68 \%$ of the respondents reported that they find direct WCF effective for them. One student highlighted the fact that direct WCF is effective as students cannot correct the mistake without the teacher's help: "I think the direct is more effective. Because some ss [students]can't figer out the correcte answer if we didn't give them the answer correctly." Another student supported this by saying "I think when they correct it directly is better than indirect correction because in the direct is clear, but in the indirect Ss might not got the correct answer." A third student said that a teacher's providing direct WCF helps him/her to avoid ambiguity: "In my opinion, the direct feedback is more effective way for corrective feedback instead of being ambigious." The fact that the majority of the students in this study preferred direct WCF is in line with Chandler's (2003) findings - that direct WCF is more effective than indirect.

On the other hand, having only $28 \%$ of the students finding that indirect WCF is effective for them disagrees with some previous research findings, such as Brandl's (1995) and Ferris and Roberts's (2001) - that most students prefer indirect WCF. Among the seven students who preferred indirect WCF for this study, one wrote, "I prefer not to write the correct one the teacher have to report the students their mistakes and let then to think what are the correct one?" Another student also reported that "crossing the wrong word without writing the correct one, so that will let me to search about the correct one and find the correct use of the mistaken one. By that, I will hit 2 birds by one rock." A third student noted that "indirect feedback is effective for me, because it improves learning and self-dependent where I will correct the wrong answers by myself instead of teacher." It is worth highlighting that the students who preferred the indirect WCF have valid reasons such as being independent learners who can pinpoint their mistakes and find out the correct use of the language item.

Only one student expressed his preference of both types of WCF. He explained this by writing, "Go indicate the wrong preposition only, will help us look deeper and search by ourselves for the correct one. But writing the correct one would be helpful as we will know the correct use. Indicating the error is more effective."

\section{Is WCF alone sufficient or is it not?}

Regarding whether WCF alone is adequate to help students learn from their misuse of English prepositions, $80 \%$ of the respondents reported that WCF alone is not enough. They emphasized the importance of further explanations and discussions about their mistakes in order not to commit them again. One of the respondents wrote, "Teacher must not only indicate to the position of the error, but also she or he must give more explanation about that error and the rule of that error." Another reported, "Crossing and correcting alone is not enough. Providing explanation of the rules will help the students to grasp the information and prevent them from repeating the same errors again." A third one responded, "No, it is not enough, because I need full explanation for the rules which will help me to recognize the reasons of mistakes."

According to Shintani and Ellis (2013), metalinguistic explanation (ME) "encourages greater depth of processing on the part of the students as they have to apply the ME to their own errors" (p. 228). Furthermore, Bitchener, Young, and 
Cameron (2005) pointed out that ME alongside WCF is beneficial for developing students' writing accuracy. In fact, ME can be either oral or written (see Bitchener \& Knoch, 2008; 2009a; 2009b). Twelve percent of the respondents indicated that whether WCF alone is enough depends both on the students' level and on the difficulty level of the prepositions in question. One of the students wrote, "Actually, it depends on the level of the students, if they are adult, you just cross and give the correct the correct one bat if they are yong you should tell them that this is right and so on." Another one wrote, "It depends on the level of the difficulty of the prepositions." The third student also reported, "It depends on the rule and the students level. For me it is better to get the correction with the rules, because whenever I know the rule and I missed it or I don't know it and I have done the mistake the rule will be with me when I write it."

Only two students (12\%) expressed the belief that WCF alone is enough. One of them was concerned with the time ME may consume: "In my opinion correctione alone is enough to help students. Because if you give them feedback that will take a lot of time." The other student highlighted the importance of giving students a chance to further explore their mistakes: "Yes, it is enough. Teacher can discuss the mistake with the student as a revision and give him a chance to learn by him/herself."

\section{Focused or unfocused WCF}

Regarding students' views on focused and unfocused WCF, $88 \%$ of the respondents expressed their preference for focused WCF as they reported that it facilitates learning from their mistakes, reduces frustration and helps them narrow down their attention to particular points at a time. They also pointed out that focused WCF is organized, effective, motivating and clear. One of the respondents reported, "I think it is more useful for [students] to have focused written corrective feedback because while they are writing they will give more attention to that area and then they will aware and learn more about it." Another one wrote, "Focused written corrective feedback, because that will help [students] to not mix or get confused. At the other hand, I think it depends on the [students'] age and level. Because old learners can understand more, so it is good for them if they learn without focused." A third student wrote, "The focused type is better me as a learner and as a student, since they don't have to meet all their mistakes in one time otherwiase they will get frustrated, or in pressure, you have to give feedback step by step." Students' perception about focused WCF is supported by Ellis (2009) who pointed out that focused WCF raises students' attention to the errors they committed, helps them pay more attention to their errors, and may lead to enhanced learning.

On the other hand, only $12 \%$ of the students expressed their preference for unfocused WCF. Those three students expressed this preference based on the belief that unfocused WCF will encourage them to ask their teachers questions about their mistakes and that students should learn everything at once. One of them wrote, "Unfocused corrective would be better, which will encourage the [students] to ask the [teacher]" The second student wrote, "Unfocused. I think students should to learn everything at one time. All skills improved together so we need to corrective all the answers." And the third one wrote, "Unfocused, everything at one time is good and the feedback will saved in minds."

In light of the above responses to the open-ended questionnaire, direct-focused WCF followed by ME is effective according to the students' views and experiences. That is, almost $50 \%$ of the students reported that they are used to receiving direct WCF on their misuse of English prepositions in their writing. Nearly $70 \%$ of those students expressed their preference for direct WCF as it is rich in information about their errors, is clear, is effective, helps them to be confident, and improves their learning. Eighty percent of the students expressed the belief that ME is important alongside WCF because they need to have further explanations on their mistakes and how to avoid them in the future. Furthermore, $88 \%$ of the students who took part in this study preferred focused WCF because it is clear and organized. They also reported that focused WCF facilitates learning, and helps them focus on their mistakes.

\section{Discussion and Conclusions}

In the present study, the researcher investigated the effectiveness of WCF on Omani students' accuracy in the use of ten commonly confused English preposition usages by Arab speakers. This study adds to the existing literature on WCF and provides pedagogical implications. The findings and answers to the two research questions will be discussed in turn.

\subsection{Research Question 1}

The quantitative data show that WCF is effective in that it helps students overcome their mistakes and learn to be more accurate users of English prepositions. That is, at the very beginning of the study the two groups did not perform well in the pre-test, which might have been due to lack of knowledge of the correct use and lack of feedback guiding them to the correct use of the target prepositions. For the immediate post-test, after experimental group treatment, a dramatic increase took place in the experimental group's scores while the control group did not improve much. This finding suggests that the WCF, which was supported with an oral meta-linguistic tutorial, is effective (see Bitchener, Young, \& Cameron, 2005; Shintani \& Ellis, 2013). The same positive results appeared in the delayed post-test. The quantitative findings have implications for the study context where WCF should be given importance to help students improve their English writing. These findings also provide more evidence to the existing research in support of the effectiveness of WCF (e.g. Ashwell, 2000; Bitchener et al., 2005; Bitchener, 2008; Bitchener \& Knoch, 2008; 2009a; 2009b; Chandler, 2003; Ellis et al., 2008; Ferris, 1995; 1999; 2002; Ferris \& Roberts, 2001; Hyland, 1998; Sachs \& Polio, 2007; Sheen, 2007; Sheen et al., 2009). 
According to the qualitative data analysis, students are not against WCF. In fact, they highlighted its importance in assisting them in improving their English. This finding is in accordance with previous studies that showed the students' preference for WCF (e.g. Ferris \& Roberts, 2001; Hyland, 1998; Lee, 2004). The findings also suggest that WCF would be stronger if it is supported with $\mathrm{ME}$ as ME helps students further understand their errors and learn from them (Ellis, 2009). Furthermore, the qualitative data analysis shows that in order for WCF to be more effective, it should focus on specific mistakes at a time in order not to confuse the students, especially those who are at their beginning level of study. This finding also supports some previous studies in this regard (see Ashwell, 2000; Bitchener, 2008; Bitchener \& Knoch, 2008; Bitchener, Young, \& Cameron, 2005; Chandler, 2003; Ellis, Sheen, Murakami, \& Takashima, 2008; Ferris, 1997; Ferris \& Roberts, 2001).

\subsection{Limitations of the Study and Future Research}

Some limitations of this study, however, are worth mentioning. First, in the present study, the researcher looked at the effect of WCF for only a short period of time, 7 weeks, for logistical reasons. Future research would better last for a whole academic semester or a year in order to have a better understanding of how learners uptake, process, and retain WCF - such as by observing the effects of WCF when including more post-tests in the design. Second, the qualitative data could have been more focused and richer if it were collected through, for example, focus group interviews.

Given the limitations of this present study as well as the findings and the research design, future researchers need to look into the effect of WCF on other linguistic features and/or in a new context, taking into account the limitations of this study.

\section{Acknowledgements}

I would like to express my genuine gratitude to all the students who took part in this study. Without their participation the completion of this study would not have been possible. Also, I would like to thank Aek Phakiti and Holi Ibrahim Holi Ali for their continuous support and feedback. Thanks are also due to the anonymous editors for their fruitful feedback and constructive comments on the study.

\section{References}

Al Khotaba, E. (2013). Errors in the use of prepositions and adverb particles by Arab ESL speakers: Performance analysis perspective. International Journal of Linguistics, 5, 273-282. doi:10.5296/ijl.v5i1.3310

Ashwell, T. (2000). Patterns of teacher response to student writing in multiple-draft composition classroom: Is content feedback followed by form feedback the best method? Journal of Second Language Writing, 9, 227-257. doi:10.1016/S1060-3743(00)00027-8

Bitchener, J. (2008). Evidence in support of written corrective feedback. Journal of Second Language Writing, 17, 102118. doi:10.1016/j.jslw.2007.11.004

Bitchener, J., \& Knoch, U. (2008). The value of written corrective feedback for migrant and international students. Language Teaching Research, 12, 409-431. doi:10.1177/1362168808089924

Bitchener, J., \& Knoch, U. (2009a). The contribution of written corrective feedback to language development: A ten month investigation. Applied Linguistics, 31, 193-214. doi:10.1093/applin/amp016

Bitchener, J., \& Knoch, U. (2009b). The relative effectiveness of different types of direct written corrective feedback. System, 37, 322-329. doi:10.1016/j.system.2008.12.006

Bitchener, J., Yong, S., \& Cameron, D. (2005). The effect of different types of corrective feedback on ESL student writing. Journal of Second Language Writing, 14, 191-205. doi:10.1016/j.jslw.2005.08.001

Brick, J. (2004). China: A handbook in intercultural communication. Sydney, NSW: National Centre for English Language Research, MacQuaire University.

Bohannon, J. \& Bonvillian, (2009). The theoretical approaches to language acquisition. In J. Berko Gleanson (Ed.), The development of language. New York, NY: Macmillan.

Brandl, K. K. (1995). Strong and weak students' preferences for error feedback options and responses. The Modern Language Journal, 79, 194-211. doi:10.1111/j.1540-4781.1995.tb05431.x

Bruton, A. (2009). Designing research into the effects of grammar correction in L2 writing: not so straightforward. Journal of Second Language Writing, 18, 136-140. doi:10.1016/j.jslw.2009.02.005

Chandler, J. (2003). The efficacy of various kinds of error feedback for improvement in the accuracy and fluency of L2 student writing. Journal of Second Language Writing, 12, 267-296. doi:10.1016/S1060-3743(03)00038-9

Creswell, J. (2009). Research design qualitative, quantitative, and mixed methods approaches. London: Sage Publications.

Creswell, J. (2014). Research design qualitative, quantitative, and mixed methods approaches. (4th Ed.). London: Sage Publications.

Dörnyei, Z. (2007). Research methods in applied linguistics. Oxford: Oxford University Press. 
Dörnyei, Z., \& Taguchi, T. (2010). Questionnaires in second language research: construction, administration and processing. London: Routledge.

Ellis, R. (2009). A typology of written corrective feedback types. ELT Journal, 63(2), 97-107. http://dx.doi.org/10.1093/elt/ccn023

Ellis, R., Sheen, Y., Murakami, M., \& Takashima, H. (2008). The effects of focused and unfocused written corrective feedback in an English as a foreign language context. System, 36, 353-371. doi:10.1016/j.system.2008.02.001

Fazio, L. (2001). The effects of corrections and commentaries on the journal writing accuracy of minority- and majority-language students. Journal of Second Language Writing, 10, 235-249. doi:10.1016/S1060-3743(01)00042-X Ferris, D. R. (1995). Teaching ESL composition students to become independent self-editors. TESOL Journal, 4, $18-22$. Ferris, D. R. (1997). The influence of teacher commentary on student revision. TESOL Quarterly, 31, 315-339. doi: $10.2307 / 3588049$

Ferris, D. R. (1999). The case for grammar correction in L2 writing classes: A response to Truscott (1996). Journal of Second Language Writing, 8, 1-12. doi:10.1016/S1060-3743(99)80110-6

Ferris, D. R. (2002). Treatment of error in second language student writing. Ann Arbor, MI: University of Michigan Press.

Ferris, D. R. (2003). Response to student writing: Implications for second language students. Lawrence Erlbaum Associates.

Ferris, D. R. (2004). The "Grammar Correction" debate in L2 writing: Where are we, and where do we go from here? (and what do we do in the meantime...?). Journal of Second Language Writing, 13, 49-62.

doi:10.1016/j.jslw.2004.04.005

Ferris, D. R. (2010). Second language writing research and written corrective feedback in SLA. Studies in Second Language Acquisition, 32, 181- 201. doi:10.1017/S0272263109990490

Ferris, D. R., \& Roberts, B. (2001). Error feedback in L2 writing classes: How explicit does it need to be? Journal of Second Language Writing, 10, 161-184. doi:10.1016/S1060-3743(01)00039-X

Fromkin, V., Rodman, R., \& Hyams, N. (2003). An introduction to language (7th ed.). Boston, MA: Thomson. Fromkin, V., Rodman, R., \& Hyams, N. (2011). An introduction to language (9th ed.). Boston, MA: CENGAGE Learning.

Gass, S. (2010). Experimental research. In B. Paltridge, \& A. Phakiti (Eds.), Continuum companion to research methods in applied linguistics (pp. 7-21). London: Continuum.

Gass, S. M., \& Selinker, L. (2008). Second language acquisition: An introductory course (3rd ed.). New York, NY: Routledge.

Guénette, D. (2007). Is feedback pedagogically correct?: Research design issues in studies of feedback on writing. Journal of Second Language Writing, 16, 40-53. doi:10.1016/j.jslw.2007.01.001

Han, Z. (2004). Fossilization in adult second language acquisition. Clevedon: Multilingual Matters Ltd.

Hyland, F. (1998). The impact of teacher written feedback on individual writers. Journal of Second Language Writing, 7, 255-286. doi:10.1016/S1060-3743(98)90017-0

Hyland, K., \& Ann, E. (2006). Teachers' perceptions of error: the effects of first language and experience. System, 34, 509-519. doi:10.1016/j.system.2006.09.001

Kharma, N. \& Hajaj, A. (1997). Errors in English among Arab speakers: Analysis and remedy (Arabic Edition). Beirut: York Press, Librairie du Liban.

Kepner, C. G. (1991). An experience in the relationship of types of written feedback to the development of secondlanguage writing skills. Modern Language Journal, 75, 305-313. doi:10.1111/j.1540-4781.1991.tb05359.x

Krashen, S. D. (1982). Principles and practice in second language acquisition. New York, NY: Pergamon Press.

Lalande, J. F. (1982). Reducing composition errors: an experiment. The Modern Language Journal, 66, 140-149. doi:10.1111/j.1540-4781.1982.tb06973.x

Lee, I. (2004). Error correction in L2 secondary writing classrooms: The case of Hong Kong. Journal of Second Language Writing, 13, 285-312. doi:10.1016/j.jslw.2004.08.001

Li, S. (2012). The effects of input-based practice on pragmatic development of requests in L2 Chinese. Language Learning, 62, 403-438. doi:10.1111/j.1467-9922.2011.00629.x

Lightbown, P. M., \& Spada, N. (2006). How languages are learned (3rd ed.). Oxford: Oxford University Press.

Mitchell, R., \& Myles, F. (2004). Second language learning theories (2nd ed.). London: Hodder Arnold.

Nicol, D. J., \& Macfarlane-Dick, D. (2006). Formative assessment and self-regulated learning: A model and seven principles of good feedback practice. Studies in Higher Education, 31, 199-218. doi:10.1080/03075070600572090

Ortega, L. (2009). Understanding second language acquisition. London: Hodder Arnold. 
Pallant, J. (2011). SPSS survival manual (4th ed.). NSW: Open University Press.

Paltridge, B., Harbon, L., Hirsch, D., Shen, H., Stevenson, M., Phakiti, A., \& Woodrow, L. (2009). Teaching academic writing: An introduction for teachers of second language writers. Ann Arbor, MI: The University of Michigan Press.

Pinker, S. (1989). Learnability and cognition. Cambridge, MA: MIT Press.

Polio, C., Fleck, C., \& Leader, N. (1998). “If only I had more time”: ESL learners' changes in linguistic accuracy on essay revisions. Journal of Second Language Writing, 7, 43-68. doi:10.1016/S1060-3743(98)90005-4

Qi, D. S., \& Lapkin, S. (2001). Exploring the role of noticing in a three-stage second language writing task. Journal of Second Language Writing, 10, 277-303. doi:10.1016/S1060-3743(01)00046-7

Robb, T., Ross, S., \& Shortreed, I. (1986). Salience of feedback on error and its effect on EFL writing quality. TESOL Quarterly, 20, 83-93.

Roberts, F. \& Cimasko, T. (2008). Evaluating ESL: Making sense of university professors' responses to second language writing. Journal of Second Language Writing, 17, 125-143. doi:10.1016/j.jslw.2007.10.002

Sachs, R., \& Polio, C. (2007). Learners' uses of two types of written feedback on a L2 writing revision task. Studies in Second Language Acquisition, 29, 67-100. doi:10.1017/S0272263107070039

Salkind, N. J. (2012). 100 questions and answers about research methods. London: Sage Publications Ltd.

Saxon, M. (2010). Child language acquisition and development. London: SAGE Publications Ltd.

Sheen, Y. (2007). The effect of focused written corrective feedback and language aptitude on ESL learners' acquisition of articles. TESOL Quarterly, 41, 255-283. doi:10.1016/j.system.2008.02.001

Sheen, Y., Wright, D., \& Moldawa, A. (2009). Differential effects of focused and unfocused written correction on the accurate use of grammatical forms by adult ESL learners. System, 37, 556-569. doi:10.1016/j.system.2009.09.002

Sheppard, K. (1992). Two feedback types: Do they make a difference? RELC Journal, 23, 103-110. doi:10.1177/003368829202300107

Shintani, N., \& Ellis, R. (2013). The comparative effect of direct written corrective feedback and metalinguistic explanation on learners' explicit and implicit knowledge of the English indefinite article. Journal of Second Language Writing, 22, 286-306. http://dx.doi.org/10.1016/j.jslw.2013.03.011

Storch, N., \& Wigglesworth, G. (2010). Learners' processing, uptake, and retention of corrective feedback on writing. Studies in Second Language Acquisition, 32, 303-334. doi:10.1017/S0272263109990532

Truscott, J. (1996). The case against grammar correction in L2 writing classrooms. Language learning, 46, 327-369. doi:10.1111/j.1467-1770.1996.tb01238.x

Truscott, J. (1999). What's wrong with oral grammar correction? The Canadian Modern Language Review, 55, 437-456

Truscott, J. (2004). Evidence and conjecture on the effects of correction: A response to Chandler. Journal of Second Language Writing, 13, 337-343. doi:10.1016/j.jslw.2004.05.002

Truscott, J. (2007). The effect of error correction on learners' ability to write accurately. Journal of Second Language Writing, 16, 255-272. doi:10.1016/j.jslw.2007.06.003

Truscott, J. (2009). Arguments and appearances: A response to Chandler. Journal of Second Language Writing, 18, 5960. doi:10.1016/j.jslw.2008.09.001

Truscott, J., \& Hsu, A. Y. (2008). Error correction, revision, and learning. Journal of Second Language Writing, 17, 292-305. doi:10.1016/j.jslw.2008.05.003

Wagner, E. (2010). Survey research. In B. Paltridge, \& A. Phakiti (Eds.), Continuum companion to research methods in applied linguistics (pp. 22-38). London: Continuum.

Wexler, K., \& Culicover, P. (1980). Formal principals of language acquisition. Cambridge, MA: MIT Press.

White, L. (1989). Universal grammar and second language acquisition. Amsterdam: John Benjamins Publishing Company.

Yockey, R. D. (2011). SPSS demystified: a step-by-step guide to successful data analysis. Boston, MA: Longman. 


\section{Appendix 1}

The table below shows the target features of this study, the ten commonly confused preposition uses by

Arab speakers of English.

\begin{tabular}{|l|l|l|}
\hline \multicolumn{2}{|c|}{ Incorrect Use by Arab Speakers of English } & \multicolumn{1}{c|}{ Correct Use } \\
\hline 1 & married from/ with & married to \\
\hline 2 & kind with & kind to \\
\hline 3 & apologizes from & apologizes to \\
\hline 4 & arrives to & arrives at \\
\hline 5 & afraid from & afraid of \\
\hline 6 & angry from & angry with \\
\hline 7 & deprived from & deprived of \\
\hline 8 & died from & died of \\
\hline 9 & independent from & independent of \\
\hline 10 & laugh from/on & laugh at \\
\hline
\end{tabular}

\section{Appendix 2}

Write no more than $\mathbf{1 0 0}$ words about Salem. You have to use the following information to help you write the paragraph.

- Salem / English teacher

- Married / Lila

- Kind / her

- He / mistake / apologize / her

- live / Barka

- work / Muscat

- finish / work / 5 pm

- Arrive / Barka / 6 pm

- Afraid / strange / people

- He / angry / boss

- Boss / deprive / Salem / freedom

- Salem's mother / died / cancer

- Future / Salem / want / independent / his father

- People / laugh / this idea

\section{Appendix 3}

Task: Complete the following sentences with the correct preposition.

1. I am angry my teacher. He always gives us homework.

2. I got a new job. This means I will be independent my parents.

3. In the past, many people died cholera.

4. Some people are deprived food.

5. My friend is married Suad.

6. They arrived the village in the morning.

7. Please do not laugh me.

8 . Salem is very kind his wife.

9. I am afraid dogs.

10. I apologized my friend.

\section{Appendix 4}

Below are the open-ended questionnaire items:

1. What kind of WCF do you usually receive on your writing?

2. What kind of WCF do you think is effective for your misuse of English prepositions in your writing?

3. Is WCF alone enough to help you learn from your misuse of English prepositions in your writing? Why?

4. Which is better for you, focused WCF or unfocused? Why? 